\title{
A NOTEWORTHY NEW NATURAL HYBRID IN THE GENUS OERSTEDELLA RCHB.F. (ORCHIDACEAE: LAELIINAE)
}

\author{
FRANCO PUPULIN $^{1}$ and ERIC HÁGSATER ${ }^{2}$ \\ ${ }^{1}$ Jardín Botánico Lankester, Universidad de Costa Rica. Research Associate, Marie Selby Botanical Gardens \\ Apdo. 1031-7050 Cartago, Costa Rica, A.C. fpupulin@ cariari.ucr.ac.cr \\ ${ }^{2}$ Herbario AMO, Apartado Postal 53-123, México, 11320 D.F. México. herbamo@ prodigy.net.mx
}

\begin{abstract}
The natural hybrid Oerstedella $\times$ monteverdensis (O. endresii $\times$ O.exasperata), from the Monteverde area, Cordillera de Tilarán, and from the northern slopes of the Cordillera de Talamanca, Costa Rica, is described and illustrated. The flowers show intermediate characters between the putative parents. Sepals and petals are pale golden brown, and the lip white flushed with violet. The new natural hybrid is similar to $O$. endresii in the verrucose stems, the glabrous abaxial surface of the sepals and the entire margins of the lateral lobes of lip; it is similar to $O$. exasperata in vegetative architecture, as well in the narrow isthmus of the lip and the prominent central keel of the midlobe.

RESUMEN. Se describe e ilustra el híbrido natural Oerstedella $\times$ monteverdensis (O. endresii $\times$ O. exasperata) del área de Monteverde, Cordillera de Tilarán, y de la vertiente septentrional de la Cordillera de Tilarán, Costa Rica. Las flores presentan características intermedias entre los parientes putativos. Sépalos y pétalos son de color café claro dorado, el labelo es blanco con una mancha ligera color violeta. El nuevo híbrido natural es similar a $O$. endresii en los tallos verrugosos, la superficie de los sépalos abaxialmente glabra y los lóbulos laterales del labelo enteros; es similar a $O$. exasperata en la aquitectura vegetativa, así como en el istmo del labelo estrecho y en la quilla prominente del lóbulo medio.
\end{abstract}

Key words / Palabras Clave: Oerstedella endresii, Oerstedella exasperata, Oerstedella $\times$ monteverdensis, natural hybrids, Orchidaceae, Costa Rica.

The orchid flora of Monteverde, Costa Rica, is perhaps one of the best studied in southern Mesoamerica due to the continuous presence of resident botanists, the relative accessibility of most of the forested areas, and the unusual commitment to conservation by the local community (for a review of botanical activities in Monteverde see Nadkarni \& Whellwright 2000). The geographic position of Monteverde, on the continental divide of the Cordillera de Tilarán, supports a wide variety of vegetation types, ranging from the seasonal forest in lowest areas and dry rocky ridges of the Pacific watershed to the elfin forest along the exposed peaks facing the Caribbean plains (Haber 2000). According to Tosi (1969), seven of the 12 life zones of Costa Rica are represented at Monteverde. This system of overlapping life zones and vegetation types also give raise to a especially rich flora, of which the epiphytic component is perhaps the most outstanding. A preliminary checklist of the vascular flora of Monteverde was published by Haber, accounting for more than 2000 species in 185 families (Haber 1991), 275 of which are orchids. An update of this list (Haber 2000) contains 3021 species. Nadkarni (1986) and Ingram et al. (ca. 1995, 1996) emphasized the occurrence of epiphytic taxa in the upper part of Monteverde cloud forest preserve (known as the "Triangle"), including 139 species of Orchidaceae, and Atwood $(1989,2000)$ concentrated on the treatment of the orchid family, recording some 400 species from Monteverde area (Atwood 2000).

The genus Oerstedella forms a distinct group within the Laeliinae, for long time considered congeneric with Epidendrum L. However, the flowers of Oerstedella have a rather fleshy, sinuous rostellum which lies perpendicular to the column axis (in Epidendrum it is parallel to the column) and lacks a clearly definied viscidium, so that only a portion of the glue from the underside of the rostellum is removed by pollinators. On the contrary, Epidendrum has a sharply defined viscidium which is removed together with the pollinia leaving a slit in the rostel- 
lum (Dressler 1982). The genus comprises some 35 species distributed from southeastern Mexico to Bolivia, but it is primarily Central American, with a center of distribution in Costa Rica and Panama (Hágsater 1991). In Costa Rica 14 species has been recorded so far, two of which are endemics (Pupulin 2002). Haber (1991) recorded 5 Oerstedella species from Monteverde area, and Ingram et al. (ca. 1995) reported 3 species from the "Triangle"; among them, $O$. endresii (Rchb.f.) Hágsater is enlisted as uncommon, and O. exasperata (Rchb.f.) Hágsater as a common, erect shrub. Six species were included by Atwood (2000) in his checklist of Monteverde orchids.

A plant vegetatively similar to $O$. exasperata, but with the sheaths of the stems obviously verrucose, was collected in Monteverde in 1998, and since then it flowered repeatedly at Monteverde Orchid Garden. Like O. exasperata, it has very tall (to more than $2 \mathrm{~m}$ long), somewhat prolific stems, the disc of the lip is violet around the callus, the apical lobes of the lip are erose, and the narrow isthmus presents a prominent keel. The flowers are fragrant, like some specimens of $O$. exasperata. It is similar to $O$. endresii in the verrucose sheaths of the stem, the apical inflorescence, the sepals adaxially glabrous, the petals obovate and rounded, and the basal lobes of the lip subrectangular, apically subcuadrate and entire. Both $O$. endresii and $O$. exasperata were previously reported from Monteverde (Haber 1991: based on Haber 9050 and Haber 1106 respectively, Ingram et al. ca. 1995, Atwood 2000: based on Haber 9050 and Haber 8813 respectively).

Another specimen referable to the same taxon is a collection by E. Hágsater and C.H. Horich from the northern slopes of the Cordillera de Talamanca, where it is sympatric with $O$. endresii, O. exasperata, and $O$. parviexasperata Hágsater. The plant flowered for the first time in the greenhouses of $\mathrm{AMO}$, in Mexico, in May 1982, and at that time it was supposed to be a form of $O$. endresii. Flowering again in January, 1983, it was included under $O$. exasperata. Then in April, 1983, when other specimens of O. exas perata and $O$. parviexasperata flowered simultaneously, it was clear that, although superficially similar, the three taxa present very obvious differences.
Oerstedella x monteverdensis Pupulin \& Hágsater, nothosp. nov.

TYPE: Costa Rica. Puntarenas: Monteverde, Cerro Plano, finca Beeche, 10¹9'13'N 8448'35'W, $1550 \mathrm{~m}$, epiphytic on old trees along pastures, lower montane cloud forest, collected by G. Barboza, 1998, flowered in cultivation at the Orchid Garden in Monteverde, 2 June 2001, F. Pupulin 3216 (holotype, USJ; clonotype in cultivation at the Orchid Garden, Monteverde).

FIG. 1-3.

Planta epifitica caulibus prolificis foliaceis verrucosis usque ad $2 \mathrm{~m}$ longis, floribus intermedis inter Oerstedellam endresii (Rchb.f.) Hágsater et O. exasperatam (Rchb.f.) Hágsater, sepalis petalisque melleis-umbrinis, labello albo maculis violaceis dilute notato, sepalis abaxialiter glabris, lobulis lateralibus labelli integris (atque O. endresii), isthmo labelli gracili, lobo mediano carina prominente ornato (atque $\mathrm{O}$. exasperatam).

Plant epiphytic, cespitose, with erect, elongate, prolific, stems $20-200 \mathrm{~cm}$ long, 2-4 $\mathrm{mm}$ in diameter, covered by verrucose sheaths, the distal half of the stem foliaceous. Roots flexuous, glabrous, thick, 2.5$4 \mathrm{~mm}$ in diameter. Leaves distichous, articulate, narrowly lanceolate to elliptic-lanceolate to ovate, minutely bilobed at apex, amplexicaul at the base, subcoriaceous, dorsally carinate, $2.4-5.6 \mathrm{~cm}$ long, 0.8-2.4 cm wide. Inflorescence apical, racemose, somewhat fractiflex, few-(4-5)flowered, to $4 \mathrm{~cm}$ long. Floral bracts triangular-cucullate to triangular-ovate, acute to apiculate, 2.5-4 mm long, 2.5-10 mm wide. Ovary pedicellate, glabrous, subclavate, $1.7-2.5 \mathrm{~cm}$ long including the pedicel. Flowers showy, sweetly scented, with sepals and petals pale yellow-cream to very pale green, the sepals sometimes tinged light brown, the lip cream-white to white with a rose blotch on the isthmus, the callus yellow, the column cream-white with the apex of clinandrium violet. Sepals subsimilar, elliptic-oblanceolate to narrowly obovate, subacute to minutely retuse, abaxially apiculate, fleshy, glabrous; dorsal sepal 11-12 mm long, 4.3-5.0 mm wide; lateral sepals 11-12 mm long, 4.5$6.0 \mathrm{~mm}$ wide. Petals narrowly obovate, obcuneate, rounded, the distal margins somewhat crenulate-denticulate, 11-12 mm long, 4.5-6 mm wide. Lip 3- 

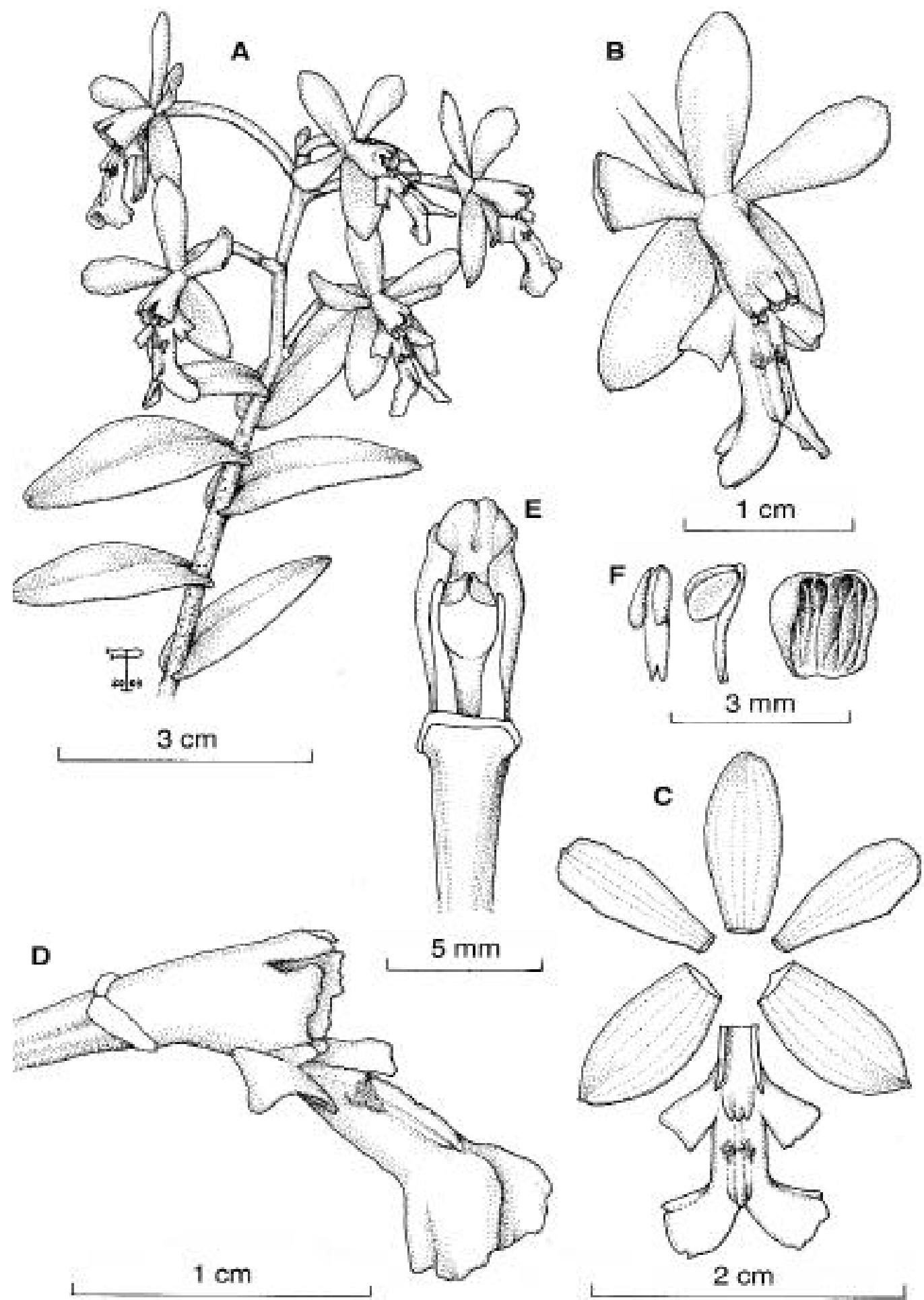

Figure 1. Oerstedella x monteverdensis Pupulin \& Hágsater. A - Inflorescence. B - Flower. C - Dissected perianth. D - Column and lip, lateral view. E - Column, ventral view. F - Pollinia and anther cap. Drawn from the holotype. 


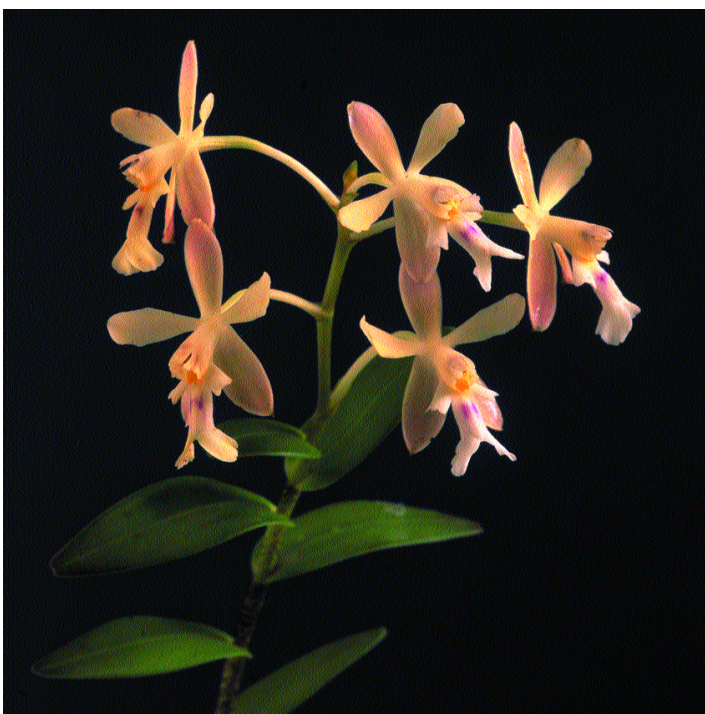

Figure 2. Oerstedella $\times$ monteverdensis. Photograph of the stem which was pressed for the holotype.

lobed, 9-16 mm long, 10-11 mm wide, with a narrow nectary extending into the pedicel; the lateral lobes subquadrate, truncate, irregularly erose-denticulate at apex, frequently with a prominent tooth in the inner side of one of the lobes, 4.5-5 mm long, 2.5-3.5 mm wide; median lobe with a rectangular isthmus $c a .5$ $\mathrm{mm}$ long, provided with a prominent, fleshy, slightly verrucose central keel extending to the apiculate apex, bifurcate at apex into two subquadrate, truncate, apically erose-denticulate lobes, $5 \mathrm{~mm}$ long, 5 $\mathrm{mm}$ wide; disc with a subquadrate callus, tridentate at apex, the median tooth extending forward into a low, slender keel. Column straight, $8 \mathrm{~mm}$ long, apically dilated, connate to the base of the lip, the clinandrium petaloid, deeply cucullate, erose at apex, 3lobed, the lateral lobes traingular, acute; the rostellum fleshy, perpendicular to the column axis, almost straight, the lateral lobes of stigma obsolete. Anther cap cucullate, subrectangular, truncate at the base, with a prominent central keel, 4-celled. Pollinia 4, obovoid, laterally complanate, to $8.3 \mathrm{~mm}$ long, the external ones slightly smaller, on 4 caudicles in two pairs, $1.6 \mathrm{~mm}$ long. Fruit not seen.

PARATYPe: Costa Rica. San José; Fila de la cordillera de Talamanca, $1 \mathrm{~km}$ al sur de Casa Mata, $1950 \mathrm{~m}$, enero y abril, 1983, E. Hágsater \& C. Horich 6320 (Horich 6320 (AMO! USJ! CR! INB!). FIG. 4.

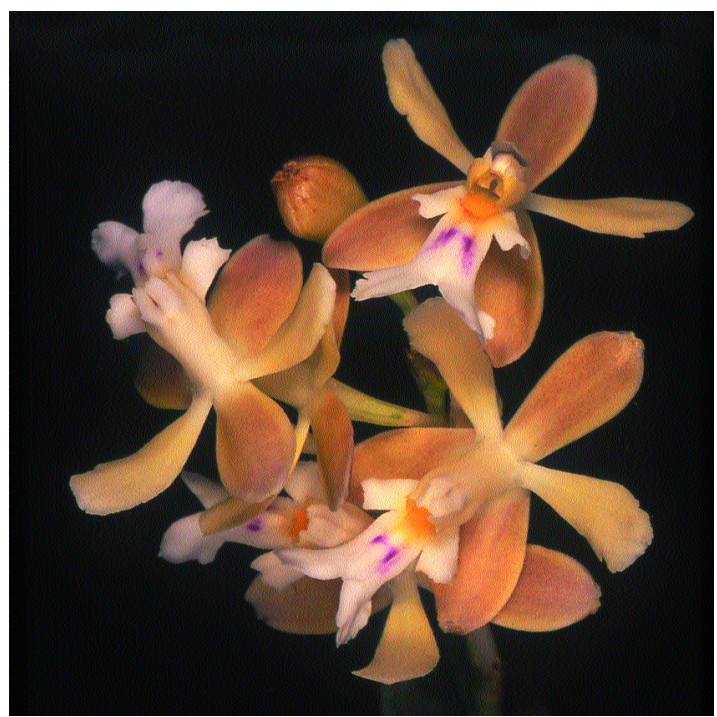

Figure 3. Oerstedella $\times$ monteverdensis. A plant in cultivation at the Orchid Garden, Monteverde.

DistRIBUTION: Known only from Costa Rica.

DERIVATION OF nAmE: From the type locality, and internationally renowned orchid "hot spot", Monteverde, Costa Rica.

ECOLOGY: A rare epiphyte in premontane and lower montane cloud forest, known from near the continental divide of Cordillera de Tilarán and the northern slopes of Cordillera de Talamanca in Costa Rica. The plants grow as medium to large epiphytes on old trees, along the edges of large areas of primary forest. Flowering occurs at least from January to July.

Oerstedella $\times$ monteverdensis may be distinguished from $O$. exasperata and $O$. parviexasperata by the glabrous, thin sepals and the cream to pale green color of the tepals. It differs from $O$. endresii by the usually tall and prolific stems, the lip with a narrow isthmus and a prominent keel, and the lateral lobes erose at apex (FIG. 5).

The phenology of the putative parents overlaps for most of the year. Oerstedella endresii flowers year round, may be with the exception of the months between July and September; phenological data by Ingram et al. (ca. 1996) from the upper Monteverde region include February and March. Flowering of $O$. exasperata has been recorded year round in Costa Rica.

Likely, another specimen of the same hybrid swarm is the collection by P.H. Allen (5387) from Vara 

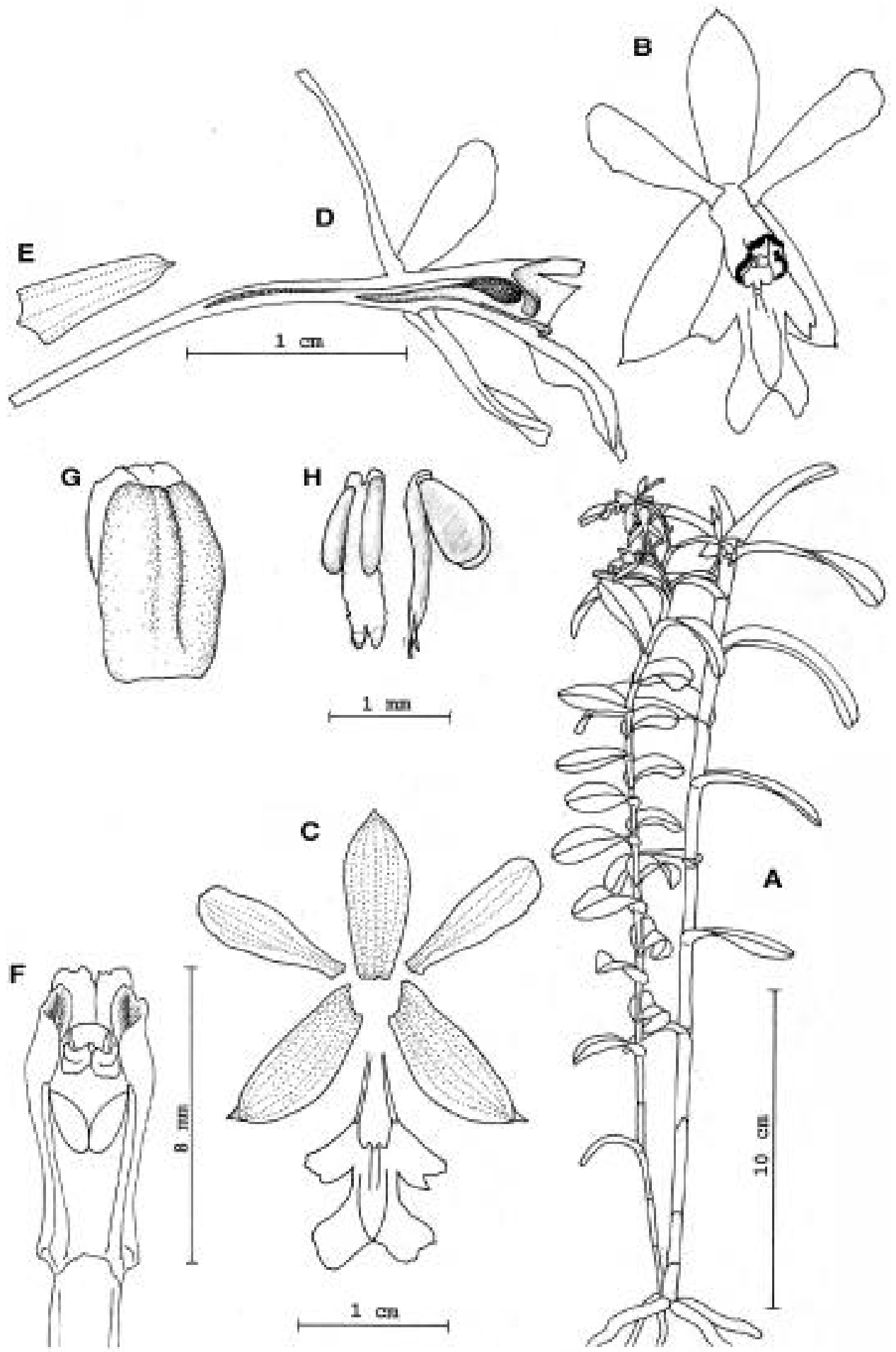

Figure 4. Oerstedella x monteverdensis Pupulin \& Hágsater. A - Habit. B - Flower. C - Dissected perianth. D - Flower and pedicel, longitudinal section. E - Flower bract. F - Column, ventral view. G - Anther cap. H - Pollinaria. VouchER: Hágsater \& Horich 6320 (AMO). 

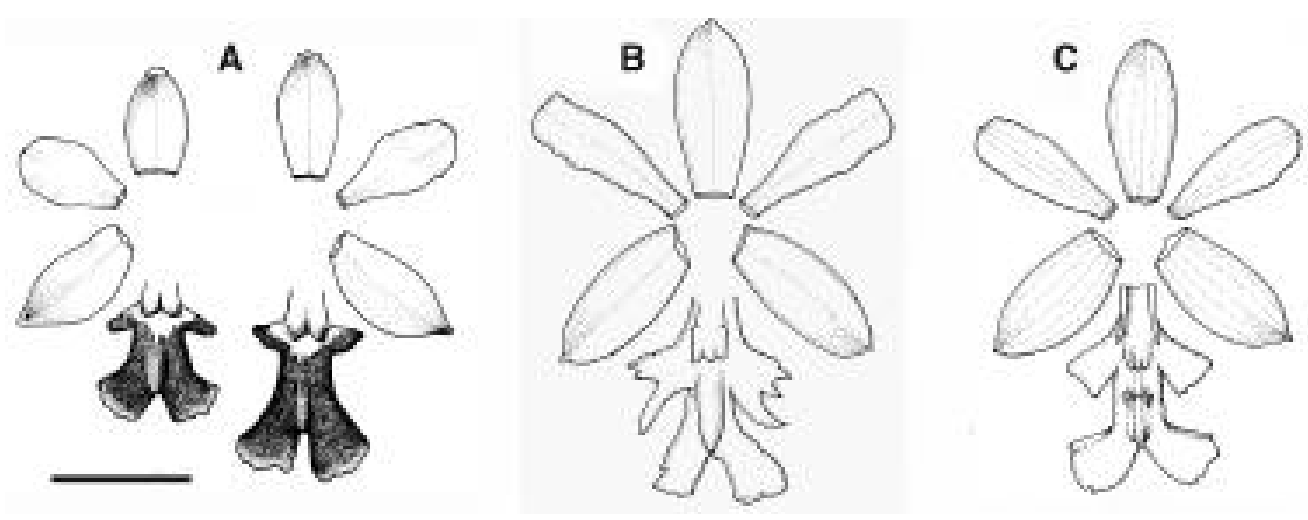

Figure 5. Dissected perianths of $O$. endresii (A), O. exasperata (B), and Oerstedella x monteverdensis (C). All drawn at the same scale. Bar $=1 \mathrm{~cm}$. Vouchers: A, Pupulin s.n., from the type locality of O. endresii; B, Hágsater 6491 (AMO, drawing); C, Pupulin 3216 (USJ).

Blanca, $2100 \mathrm{~m}$, who described sepals and petals as "greenish-yellow" and the lip as white. The flowers of O. endresii are invariably snow-white, with the lip more or less violet, and collectors' notes usually refer explicitly to the showy colors of this species.
It is worthy to note that specimens of $O$. endresii in herbaria can be assigned to two groups of plants of different height, that may be recognized on the basis of the size and shape of their leaves. A meticolous revision of the material seems necessary.

\section{Key to Costa RicAN SPECIES OF THE OERSTEDELLA EXASPERATA GROUP}

1. Sheaths of stem distinctly verrucose; sepals and petals cream; sepals adaxially glabrous ..... Oerstedella $\times$ monteverdensis

1. Sheaths of stem bare or only slightly verrucose; sepals and petals brown; sepals adaxially aculeate-verrucose 2

2. Lateral lobes of the lip plurilobate at apex, the lobes acuminate Oerstedella exasperata

2. Lateral lobes of the lip subquadrate at apex, without acuminate lobes Oerstedella parviexasperata

\section{ACKNOWLEDGMENTS}

We acknowledge Gabriel Barboza for sharing with us material in cultivation at the Orchid Garden and for his valuable comments on the orchid flora of Monteverde.

\section{LiTERATURE CiTED}

Atwood, J.T. 1989. Orchids of Costa Rica. Part 1. Icon. Pl. Trop. 14: pl. 1301-1400.

Atwood, J.T. 2000. Orchids of Monteverde. In: N.M. Nadkarni \& N.T. Wheelwright (eds.). Monteverde. Ecology and conservation of a tropical cloud forest. Oxford University Press, New York-Oxford. p. 523527.

Dressler, R.L. 1982. Two new Oerstedella from Panama. Orquídea (Méx.) 8: 343-354.

Haber, W.A. 1991 [1990]. Lista provisional de las plantas de Monteverde, Costa Rica. Brenesia 34: 63-120.

Haber. W.A. 2000. Plants and vegetation. In: N.M. Nadkarni \& N.T. Wheelwright (eds.). Monteverde. Ecology and conservation of a tropical cloud forest. Oxford University Press, New York-Oxford. p. 39-94.
Hágsater, E. 1991. Oerstedella Rchb.f. In: R. Escobar (ed.). Orquídeas nativas de Colombia. Vol. 3. Compañía Litográfica Nacional, Medellín. p.372.

Ingram, S.W., K. Ferrell-Ingram \& N. Nadkarni. [s.d., $c a$. 1995]. Epiphytes of he Monteverde Cloud Forest Reserve. The Marie Selby Botanical Gardens, Sarasota. 64 p.

Ingram, S. W., K. Ferrell-Ingram \& N. N. Nadkarni. 1996. Floristic composition of vascular epiphytes in a neotropical cloud forest. Monteverde, Costa Rica. Selbyana 17: 88-103.

Nadkarni, N.M. 1986. An ecological overview and checklist of vascular epiphytes in the Monteverde Cloud Forest Reserve, Costa Rica. Brenesia 9: 247-252.

Nadkarni, N.M. \& N.T. Wheelwright (eds.). 2000. Monteverde. Ecology and conservation of a tropical cloud forest. Oxford University Press, New YorkOxford. 573 p.

Pupulin, F. 2002. Catálogo revisado y anotado de las Orchidaceae de Costa Rica. Lankesteriana 4: 1-88.

Tosi, J.A. 1969. Mapa ecológico, según la clasificación de zonas de vida del mundo de L.R. Holdridge. Centro Científico Tropical, San José, Costa Rica. 